\title{
DETERMINATION OF THE ROLE OF FUSOBACTERIUM NUCLEATUM IN THE PATHOGENESIS IN AND OUT THE MOUTH
}

\author{
Urim Tefiku ${ }^{1}$, Mirjana Popovska ${ }^{2}$, Amella Cana ${ }^{3}$, Lindita Zendeli-Bedxeti ${ }^{3}$, \\ Bilbil Recica $^{4}$, Ana Spasovska-Gjorgovska ${ }^{5}$, Spiro Spasovski ${ }^{6}$ \\ 1 "Denta Med" Pristina, Republic of Kosovo \\ ${ }^{2}$ University Dental Clinical Centre, Department of periodontology and oral pathology, Faculty of dentistry, \\ "Ss. Cyril and Methodius University", Skopje, R.N. Macedonia \\ ${ }^{3}$ University Dental Clinical Centre, Department of periodontology and oral pathology, Skopje, R.N. Macedonia \\ ${ }^{4}$ University Dental Clinical Centre, Department of Dental Emergency-Pristina, Republic of Kosovo, \\ ${ }^{5}$ PZU "Ilinden 96" Skopje, R.N. Macedonia \\ ${ }^{6}$ „Dr. Spasovski” Skopje, R.N. Macedonia
}

Corresponding author: Nada Pop-Jordanova, Bul Krste Misirkov br.2, P.O.Box 428, 1000 Skopje, North Macedonia, e-mail: popjordanova.nadica@gmail.co

\section{ABSTRACT}

Introduction: One of the most important types of microorganisms in the oral cavity in both healthy and non-healthy individuals is Fusobacterium nucleatum. Although present as a normal resident in the oral cavity, this Gram-negative pathogen is dominant in periodontal disease and it is involved in many invasive infections in the population, acute and chronic inflammatory conditions, as well as many adverse events with a fatal outcome.

Aim: To determine the role of F. nucleatum in the development of polymicrobial biofilms thus pathogenic changes in and out of the oral media.

Material and method: A systematic review of the literature concerning the determination and role of F. nucleatum through available clinical trials, literature reviews, original research and articles published electronically at Pub Med and Google Scholar.

Conclusion: The presence of Fusobacterium nucleatum is commonly associated with the health status of individuals. These anaerobic bacteria plays a key role in oral pathological conditions and has been detected in many systemic disorders causing complex pathogenethic changes probably due to binding ability to various cells thus several virulence mechanisms.

Most common diseases and conditions in the oral cavity associated with F.nucleatum are gingivitis (G), chronic periodontitis $(\mathrm{CH})$, aggressive periodontitis $(\mathrm{AgP})$, endo-periodental infections (E-P), chronic apical periodontitis (PCHA). The bacterium has been identified and detected in many systemic disorders such as coronary heart disease (CVD) pathological pregnancy (P); polycystic ovary syndrome (PCOS), high-risk pregnancy (HRP), colorectal cancer (CRC); pre-eclampsia (PE); rheumatoid arthritis (RA); osteoarthritis (OA).

Keywords: periodontitis, fusobacterium nucleatum, pathogenesis 


\section{INTRODUCTION}

Periodontal disease is a multi-factorial inflammatory disease that has a progressive course, followed by damage to all periodontal structures, including bone destruction and consequently tooth loss. The initial inflammatory reaction occurs as a response of the host to colonizing periopathogenic bacteria. From the gingiva, the inflammatory process continues to spread deep into the tissues of the periodontium and causes loss of connective tissue and alveolar bone. Epidemiological data indicate that periodontal disease is widespread in the population and affect up to $90 \%$ of the world's population. [1]

Periodontitis is an infectious disease of the tissues surrounding the tooth, with wide range of clinical, microbiological and immune disorders therefore is considered a consequence of the dynamic interaction between infectious agents, the host's immune response, environmental exposure, and genetic predisposition. The prevalence and the relationship between bacterial species is particularly useful information in clarifying the biology of subgingival plaque. These findings may be useful in planning strategiesof plaque control that are important in establishing a new approach to the diagnosis and treatment of periodontal diseases. Literature reports that more than 500 bacterial strains can be identified in a periodontal pocket. There are also findings claiming that all sub-gingival bacteria are equally important in the initiation and progression of periodontal disease. There is good evidence to support these facts that they are caused by certain inhabitants of normal oral flora, mainly gram-negative anaerobes. [2]

Defining the composition of the oral microbiological flora is crucial in clarifying its role in healthy and diseased periodontium. Many of these types of bacteria have pathogenic potential, but only a few can be true initiators of the disease. Others probably have an associate or supplementary role. Any changes from the usual composition of the interacting microorganisms in the symbiosis, which is normal oral flora, caused by internal (genetic) or external (diet, toxins, antibiotics, etc.) factors can enhance the pathogenic potential of microorganisms in the oral medium thus the continuation and progression of periodontal destruction. This is an important point to be seriously considered when evaluating the true role of bacteria with the help of diagnostic tests based on the detection of specific microorganisms. Members of the oral medium generally coexist and thrive by forming a complex polymicrobial community, i.e. "Biofilm". Mutual communication of these species from their mutual co-evolution creates large structures known as dental plaque. With maturation of the plaque that is inevitably associated with periodontal disease, the number of gram-negative (predominantly aerobic) and anaerobic bacteria increases. [3-6] Studies have shown that the prevalence of bacteria supra-gingival to one tooth surface can exceed 1x109 bacteria. By using chewing gum, the number of bacteria is reduced and ranges from 1x103 in the gingival sulcus to more than $1 \times 108$ in the periodontal pocket. [7]

The complexity of subgingival dental plaque composition has been identified and clarified long ago, with the first microscopic examination of this ecosystem by Van Leuwenhoek in 1683. [8] Since that time, numerous studies have examined and monitored the composition of the plaque using light and electronic microscopy, with numerous additional and auxiliary techniques explaining its variations supra- or sub-gingival and their role in the periodontium.All techniques support the initial findings of Van Leuwenhoek [8], that subgingival plaque consists of a large complex of heterogeneous bacterial species. Subgingival plaque bacteria are considered the primary etiological factor for the occurrence of periodontitis, but according to some authors, only a few species, such as: A. actinomycetemcomitans, F. nucleatum, and P. gingivalis, are highlighted as major periopathogens. [9]

\section{FEATURES AND CHARACTERISTICS OF INDIVIDUAL PERIOPATHOGENS}

P. gingivalis is a bacterial strain belonging to the red complex [10] that is most commonly associated with chronic periodontitis (CP) and progression of periodontal destruction. [11] These bacteria are considered to be an important etiologic factor in severe forms of periodontal disease, i.e. they are a prominent component of the oral media and at the same time a successful colonizer of the oral epithelium. [12] At this point, researchers are trying to find out exactly how symbiosis works among bacterial populations in the mouth, especially between $\mathrm{P}$. gingivalis and F. nucleatum, as they are the main causes of gingival inflammation. Their specific role is based on interactivity with the host, although it has already been proven that neither bacterial species can survive without each other. [13] These bacteria are not only responsible for damaging the periodontium. 
Therefore, Porphyromonas gingivalis is thought to be involved in the etiology of rheumatoid arthritis and Alzhaimerdesaese. [14]

P. gingivalis and F. nucleatum, thanks to their virulent components, manage to survive in complicated environments by selectively modulating the host's immune-inflammatory response. Studies reveal that bacterial infection and the host's immune response are involved in the induction and progression of the disease. [15]

By observing, monitoring and studying certain pathogens in the periodontal disease, current evidence suggests that the prevalence of periodontal pathogenic microorganisms, such as A. actinomycetemcomitans and P. gingivalis, differs between ethnic groups. Such differences appear to be related to host tropism (i.e., specific adaptation of subpopulations of bacterial subspecies to certain host genetic genera) rather than differences in geographic influence and living conditions. [16]

The importance of F. nucleatum in the development of polymicrobial biofilms has been fairly long researched, discussed, explained, and more recently partially proven. F. nucleatum acts as a bridge mediating the co-coherence of late disease-causing colonizers, including P. gingivalis, as a component of the dental biofilm. Co-infection with F. nucleatum may increase the potential for adhesion and invasion of $\mathrm{P}$. gingivalis and A. actinomycetemcomitans on gingival epithelial cells. [17]

\section{CHARACTERISTICS OF FUSOBACTERIUM NUCLEATUM}

The greatest heterogeneity of bacteria (over 700 different species) and the proximity of numerous anatomical regions where they are present, characterize the oral microbiological flora as one of the most divergent microbiomes in the human body, according to colonized microorganisms. $[18,19]$

F. nucleatum belongs to the family Bacteroidacae, at the same time the dominant microorganism within the periodontium. It is a gram-negative anaerobic strain of Fusobacteria phylum, predominant in dental plaque biofilm and an important factor in biofilm ecology and human infectious diseases.

F. nucleatum is present in the oral cavity, absent or rarely detected elsewhere in the body under normal conditions. [20,21] In medical con- ditions, however, F. nucleatum is one of the most abundant species found outside the oral cavity (in the intestine, ovaries, placenta, bronchi). F. nucleatum is a heterogeneous pathogen to which five subspecies (ss) are added, i.e. ss animalis, ss fusiforme, ss nucleatum, ss polymorphum and ss vincentii, whose prevalence in various diseases is quite heterogeneous and variable. $[22,25]$

\section{MANAGEMENT AND POSSIBLE TREATMENT MODALITIES}

People become patients when they present some medical symptoms to the doctor. The prevalence of medically unexplained symptoms ranges from $5-65 \%$ in primary care, and to $37-66 \%$ in specialty clinics. However, the prevalence is approximate, because it is hard to define what constitutes these symptoms. As we mentioned previously, in the DSM-5, this group of disorders belong to the somatoform group, because there are no diagnostic biomarkers for any other psychiatric diagnosis. In the diagnostics an intensive, deep anamnesis for all important facts in early life, as well as socio-economic state of patient, relationships and family lives are important. It needs too much time and patience, which is a problem in the contemporary lifestyle. The evaluation comprises all available methods in dentistry even fMRI. As we said before, all clinical examinations in this group of patients remain negative. The psychological evaluation is most important.

The current approaches propose to measure stress with some psychometric instruments (Perceived stress scale) and measures of affect (Profile of moods state), measures of stressor exposure (Major life events stress scale) and lastly the stress biomarkers (Cortisol, C-Reactive protein and interleukins). In our practice, we used electrodermal activity as a fast and valuable measure for stress level [25-28].

The commonly used stress biomarkers include:

- Metabolic markers - cholesterol, high-density lipoprotein (HDL) cholesterol, total cholesterol-HDL ratio, albumin, glycosylated hemoglobin;

- Immunological markers - interleukin-6 (IL-6), tumour necrosis factor (TNF- $\alpha)$, C-re- 
active protein (CRP), insulin-like growth factor (IGF-1);

- Neuroendocrine markers - cortisol, dehydroepiandrosterone (DHEA), and cortisol / DHEA ratio, adrenaline, noradrenaline, dopamine and aldosterone:

- Other parameters: i.e. arterial tension (systolic/diastolic), heart rate, electrodermal activity, brain spectral characteristics etc.

Recently, it has been shown that chronic stress alters ultrastructure of mitochondria of masticatory muscles in experimental animals. In some studies, anaerobic metabolism was shown increased, as well as the positive findings for oxidative stress. The fragmentation of mitochondria that is observed under chronic stress is due to unbalanced fission. A buccal swab can give enough cells to observe mitochondrial changes and the morphological changes of mitochondria could be used as biomarkers for chronic stress. Buccal swab collection is non-invasive and inexpensive, making ultrastructure changes in mitochondria easy to use for large epidemiological studies. The intensity of ultrastructure integrity loss can be related to the length of time under stress [29-33].

Many forms of psychotherapy can help these patients. Most frequently, the Cognitivebehavioural therapy, Self-observation, Relaxation training, Hypnotherapy, Biofeedback are used. Sometimes, the medication prescription is inevitable. As medication Antidepressants, Antianxiety drugs or even Antipsychotic drugs can be used [34-38]. Our results with biofeedback are very encouraging. For stress diminishing the peripheral biofeedback is extremely useful and has cost-beneficial effects.

\section{THE ROLE OF F. NUCLEATUM IN THE PATHOGENESIS OF PERIODONTAL DISEASE}

In clarifying the complexity of pathogenesis of periodontal disease and elucidating its role in periodontal disease, for F. nucleatum is believed to possess several virulence mechanisms that can be broadly classified into two groups: colonization and dissemination, and induction of host response. [26]

F. nucleatum is an adhesive bacterium. It co-aggregates with various microbiological spe- cies in the oral cavity, playing a key role in the formation of dental plaque. [27] It encodes several adhesins for interactions, including Fap2, RadD and aid1. [28-30] F. Nucleatum also binds to various cells in the human population, including epithelial and endothelial cells, monocytes, erythrocytes, fibroblasts, and host molecules such as salivary macromolecules, extracellular matrix proteins, etc. [26-31]

So far only one adhesin has been identified, FadA which adheres to the host cells and is one of the strongest virulence factors. [26] FadA is not only adhesin but also invasine. [32] Also F. nucleatum elicits different host responses. [26] It stimulates the production and activity of human beta-defensin 2 from oral epithelial cells via FAD-I. [33] It stimulates atherosclerosis-inducing factors by GroEL [34], activates lymphocyte apoptosis by Fap2 and RadD [30], and is a potent stimulator of inflammatory cytokines, IL-6, IL-8 and TNF. $[35,36]$ Binding of F. nucleatum to NK cells (Natural killer cells) activates inflammatory reactions involved in periodontal disease. [37] In colorectal cancer (CRC), F. nucleatum activates not only inflammatory cells but also genes, especially oncogenes and Wnt genes which are markers of tumorigenesis. FadA plays a key role in the induction of these tumors where the gene response is absent. Synthetic peptide that prevents FadA binding to E-quadrant, blocks the activation of the inflammatory response but also affects oncogenes and Wnt gene expression. [38]

The pathogenicity of $F$. nucleatum is attributed, in part, to its function as a "bridge in the organism" that supports the integration of periopathogens into oral biofilms. $[39,40]$ With this unique skill they have the ability to merge to early and the late colonizers. F. nucleatum is thought to play a central role in environmental change from predominantly gram-positive flora to predominantly gram-negative, and thus to a pathogenically transformed biofilm community that tends to initiate a progressive periodontal disease. [39]

Despite extensive research on F. nucleatum, its interspecies, interactions, and identification of a large number of binding partners, to date, only two fusobacterial large outer membrane proteins (NMPs), RadD and Fap2, are important at the molecular level as binding adhesins for different gram-positive bacterial strains, [28,29] among which most commonly Porphyromonas gingivalis. [41] RadD and 
Fap2 are members of the protein family, which are the most well-known autotransporter family and have a strong influence as virulence factors that may originate from gram-negative bacteria. [42] Auto-transporters have numerous biological functions including adhesion $[43,44]$ cell aggregation, biofilm formation [45-48] and their invasion. [49] It is therefore not surprising that despite their role in interspecies, i.e. binding, fusobacterial auto-transporters are multifunctional and actively involved in induction of apoptosis in lymphocytes $[29,30]$ and adherence to placental cells (demonstrated by mouse studies) . [41]

There is evidence that the prevalence of $\mathrm{F}$. nucleatum increases with the worsening of disease, progression of inflammation and deepening of pockets. [50-52] Among the five so far verified subspecies most commonly fusiforme and vincentii are most often associated with healthy status, while nucleatum with non-healthy state in the organism. [53].In the context of this explanation it is worth emphasizing that the serum titers of F. nucleatum antibodies are elevated in the sick patients. [54]

The presence of $F$. nucleatum to a greater or lesser extent is influenced by certain factors that come from the environment e.g. smoking increases the prevalence of this anaerob in both healthy and sick individuals. [54,55] In patients with chronic periodontitis, those with uncontrolled type 2 diabetes have higher levels of F. nucleatum. [56] When F. nucleatum has the role of co-infection with other oral bacterial species, e.g. Tannerella forsythia, Porphyromonas gingivalis and Streptococci, it's evident the synergy of virulence with the indicated bacterial species as evidenced by increased bone loss and creation of abscess. [57-61]

F. nucleatum is one of the most prevalent species in the oral cavity. It is involved in all forms of periodontal disease, emphasizing mild reversible forms of gingivitis or advanced irreversible forms of periodontal disease, chronic periodontal disease, localized aggressive periodontal disease, generalized aggressive periodontal disease and others. [50,51]

Moore and Moore [50] concluded that F. nucleatum is the most common cause of gingival inflammation that initiates periodontal disease and is the most dominant pathogen in periodontal destruction. The importance of F. nucleatum in the development of polymicrobial biofilms has long been proven. F. nucleatum binds to ear- ly colonizers and acts as a bridge mediating the cohesion of late colonizers that cause disease, including P. gingivalis, in the dental biofilm. Most gram-negative bacteria are associated with various forms of periodontal disease. They are asaharolytic species, but unlike them F.nucleatum can obtain energy by fermenting simple sugars such as glucose or fructose, but not sucrose; or by fermenting certain amino acids, free or in the form of small peptides. This metabolic versatility probably explains why it is found in supra and subgingival dental plaque. [62]

\section{ASSOCIATION OF FUSOBACTERIUM NUCLEATUM WITH OTHER SYSTEMIC DISEASES}

It is one of the most common oral isolated types from and beyond oral infections, including blood, brain, chest, lungs, liver, joints, abdominal, obstetric and gynecological infections.

There is evidence that F. nucleatum and Porphyromonas gingivalis synergistically increase the progression of oral cancer. [72] Studies concerning the impact of these two periodontal pathogenic bacteria indicate several virulence mechanisms that promote carcinogenesis. [73] The specific properties of virulence suggest their potent invasion into the subcutaneous and intestinal epithelium, blocking oncogene signaling, blocking their adhesion, inflammation induction, and inhibition of natural killer cells and cytotoxic T-cells, promoting tumor proliferation and progression. $[73,74]$

Gastrointestinal disorders have a particular role on this anaerobic, which is believed to contribute to the development of colorectal cancer (CRC), inflammatory bowel disease (IBD) and appendicitis. F. nucleatum is regularly identified in studies of colorectal cancer (CRC) present in the tumor microbiome, often as an adjunct to other oral microorganisms. [75] F. nucleatum was first detected in cancers and rectal swabs of patients with CRC. [76,77] Several studies have reported an association of $\mathrm{F}$. nucleatum with the appendicitis. [78-80]

There is evidence that the finding of this anaerob is associated with certain complicated conditions in the body. Complication of pregnancy is essentially a broad term, which includes preterm delivery, chorioamnonitis, premature rupture of 
Table 1. Incidence and association of fusobacterium nucleatum in oral cavity diseases

\begin{tabular}{|c|c|c|c|c|}
\hline Sample taken from & Method & $\begin{array}{l}\text { Total number } \\
\text { of patients }\end{array}$ & Related to & References \\
\hline Subgingival biofilm & PCR & 70 & G & [63] \\
\hline Subgingival biofilm & PCR & 70 & $\mathrm{CH}$ & [63] \\
\hline $\begin{array}{l}\text { Subgingival biofilm } \\
\text { and saliva }\end{array}$ & PCR & 81 & $\mathrm{AgP}$ & [64] \\
\hline $\begin{array}{l}\text { Supragingival den- } \\
\text { tal plaque }\end{array}$ & Cultivation & 30 & $\mathrm{CH}$ & [65] \\
\hline $\begin{array}{l}\text { Subgingival dental } \\
\text { plaque }\end{array}$ & Cultivation & 30 & $\mathrm{CH}$ & [65] \\
\hline $\begin{array}{l}\text { Endoperiodontal le- } \\
\text { sion }\end{array}$ & PCR & 46 & EP & [66] \\
\hline Saliva & PCR & 31 & G & [67] \\
\hline Saliva & PCR & 46 & $\mathrm{CH}$ & [67] \\
\hline Saliva & PCR & 36 & $\mathrm{Ag}$ & [67] \\
\hline Periapical lesion & r16SI DNA & 20 & PCHA & [68] \\
\hline $\begin{array}{l}\text { isolate from root in- } \\
\text { fected canals }\end{array}$ & 16S RNA (rRNA) & 87 & PCHA & [69] \\
\hline $\begin{array}{l}\text { isolate from root in- } \\
\text { fected canals }\end{array}$ & $\begin{array}{l}\text { DNA-DNA hy- } \\
\text { bridization }\end{array}$ & 24 & PCHA & [70] \\
\hline $\begin{array}{l}\text { isolate from root ca- } \\
\text { nals }\end{array}$ & PCR & 55 & G & [71] \\
\hline
\end{tabular}

Legend: G-gingivitis; AgP-aggressive periodontitis; $\mathrm{CH}$-chronic periodontitis; EP-endo-periodontitis; PCHA-chronic apical periodontitis;

membranes, preeclampsia, miscarriage, low birth weight, premature birth, neonatal sepsis, etc. In all these states, F. nucleatum is one of the most widespread species and one of the most frequently detected microorganisms. [81] It is assumed that F. nucleatum is transmitted from the mother's oral cavity to the intrauterine bed through hematogenous transmission. $[81,83]$ Of the five subspecies, only two were detected in intrauterine infection, in the majority the subspecies animalis and less the polymorphum.

F. nucleatum is associated with a wide range of infections and abscesses, including head and neck infections (Lemier syndrome, acute and chronic mastoiditis, chronic otitis and sinusitis, periodontitis, tonsillitis, peritonsillar and retropharyngeal abces, prolonged cervical lymphad- enitis) brain, lungs, abdomen, pelvis, bones and joints. [84-86]

The frequency of F. nucleatum detection in atherosclerotic plaques and blood vessels is directly related to the severity of periodontal disease. [87] Additional diseases involving F. nucleatum include rheumatoid arthritis and Alzheimer's disease. $[88,89]$ Periodontal treatment has been shown to improve the clinical outcome of rheumatoid arthritis. [89]

\section{RESULTS AND DISCUSSION}

Studies emphasise the prevalence and association of F. nucleatum with the most common diseases and conditions of the oral cavity: gingi- 
Table 2. Prevalence and association of fusobacterium nucleatum with certain systemic diseases

\begin{tabular}{|c|c|c|c|c|}
\hline $\begin{array}{l}\text { Sample taken } \\
\text { from }\end{array}$ & Method & $\begin{array}{l}\text { Total number of } \\
\text { patients }\end{array}$ & Related to & References \\
\hline $\begin{array}{l}\text { Atheromatous } \\
\text { plaques }\end{array}$ & PCR & 44 & CAD & [90] \\
\hline $\begin{array}{l}\text { Supragingival } \\
\text { biofilm }\end{array}$ & qPCR & 23 & $\mathrm{P}$ & [91] \\
\hline Saliva & qPCR & 35 & PCOS & [92] \\
\hline Amniotic fluid & $16 \mathrm{~S}$ rRNA & 46 & $\overline{\text { PTB }}$ & [93] \\
\hline Amniotic fluid & cultivation & 46 & PTB & [93] \\
\hline Oral mucosa & PCR & 24 & HRP & [94] \\
\hline Chorionic tissue & PCR & 24 & HRP & [94] \\
\hline Colon tissue & PCR & 130 & $\mathrm{CRC}$ & {$[95]$} \\
\hline Feces & ddPCR & 184 & $\mathrm{CRC}$ & [96] \\
\hline Placenta & PCR & 16 & Preeclampsia & [97] \\
\hline Fetal membrane & $16 \mathrm{~S}$ rRNA & 15 & PTB & {$[98]$} \\
\hline Fetal membrane & PCR & 43 & PTB & [98] \\
\hline Abscesses content & cultivation & 226 & Abcesus & [99] \\
\hline Lung aspirate & cultivation & 226 & Aspirational & [99] \\
\hline Nail & cultivation & 226 & $\begin{array}{l}\text { pneumonia } \\
\text { Paronychia }\end{array}$ & [99] \\
\hline $\begin{array}{l}\text { Material from the } \\
\text { middle ear }\end{array}$ & cultivation & 226 & Otitis media & [99] \\
\hline Bone & cultivation & 226 & Osteomyelitis & [99] \\
\hline Synovial fluid & 16S-23S rRNA & 11 & RA & [100] \\
\hline Synovial fluid & 16S-23S rRNA & 25 & OA & [100] \\
\hline Dental plaque & $16 \mathrm{~S}-23 \mathrm{~S}$ rRNA & 36 & $\mathrm{RA}+\mathrm{OA}$ & {$[100]$} \\
\hline
\end{tabular}

Legend: CAD- coronary artery disease; P-pregnancy; PCOS - polycystic ovary syndrome; PTB- preterm birth; HRP - high-risk pregnancy; CRC- colorectal cancer; PE-preeclampsia; RA-rheumatoid arthritis; OA-osteoarthritis.

vitis $(\mathrm{G})$, chronic periodontitis $(\mathrm{CH})$, aggressive periodontitis $(\mathrm{AgP})$, endo-periodontal infections (EP), chronic apical periodontitis (PCHA) in a variety of media: subgingival and supragingival dental plaque, fluid, saliva, tissue. The presence of this anaerobe is commonly associated with the health status of individuals.

In the body this bacteria has been identified and detected in synovial fluid, placenta, fetal membrane, lung fluid, abscess content and in many systemic disorders such as: coronary artery disease $(\mathrm{CAD})$ pathological pregnancy $(\mathrm{P})$; polycystic ovary syndrome (PCOS); high-risk pregnancy (HRP); colorectal cancer (CRC); pre-ec- lampsia (PE); rheumatoid arthritis (RA); osteoarthritis (OA). F. nucleatum is an oral commensal involved in oral infections, and in most diseases even with a fatal end. This anaerobe with quite pathogenic effects can be distributed systemically from the oral cavity by colonizing different sites in the body, or vice versa. However, the path of eradication is an issue that has not been clarified and is still open.

From the available literature it can be understood that F. nucleatum initiates a full spectrum of host responses, ranging from immune, bacteriological, toxic, enzymatic and inflammatory processes. Most authors share the opinion that 
adenine FadA of F. nucleatum and is a key virulence factor. Relying on the abundance of highly processed literature, it is clear that F. nucleatum has a rather important role in the pathogenesis of diseases of the oral cavity. Whether its role is predominant or it is secondary, it is the subject of additional research, analysis and reporting.

\section{CONCLUSION}

F. nucleatum predominates in various pathological conditions in biofilms in and out of the mouth, since its involvement in the pathogenesis of these diseases.

The presence of Fusobacterium nucleatum is commonly associated with the health status of individuals. This anaerob plays a key role in oral pathological conditions and has been detected in many systemic disorders causing complex pathogenesis probably due to binding ability to various cells thus several virulence mechanisms.

\section{REFERENCES}

1. Armitage GC. Periodontal diagnoses and classification of periodontal diseases. Periodontol 2000, 2004; 34: 9-21.

2. Lamon RJ.Jenkinson HF. Adhesion as an ecological determinant in the oral cavity. In: Kuramitsu HK, EllenRP. (eds). Oral Bacterial Ecology: The Molecular Basis. Horizon Scientific Press, Wymondham, Norfolk, UK, 2000, p. 131-168.

3. Ximenez-Fyvie LA, Haffajee AD, Socransky SS. Comparison of the microbiota of supra- and subgingival plaque in health and periodontitis. J ClinPeriodontol 2000; 27: 648-57.

4. Tanner A, Maiden MF, Macuch PJ, et al. Microbiota of health,gingivitis, and initial periodontitis. J ClinPeriodontol 1998; 25: 85-98.

5. Tanner A, Kent R, Maiden MF, et al. Clinical, microbiological and immunological profile of healthy, gingivitis and putative active periodontal subjects. J Periodontal Res 1996; 31: 195-204.

6. Ramberg P, Sekino S, Uzel NG, et al. Bacterial colonization during de novo plaque formation. $\mathrm{J}$ ClinPeriodontol 2003; 30: 990-95.

7. Socransky SS, Haffajee AD. Microbiology of periodontal disease.In: Lindhe J, Karring T, Lang NP, eds. Clinical Periodontology and Implant Dentistry. Copenhagen, Denmark: MunksgaardBlackwells, 2003.
8. Van Leewenhoeck, A. (1677). Observations, Communicated to the Publisher by Mr. Antony van Leewenhoeck, in a Dutch Letter of the 9th of Octob. 1676. Here English'd: concerning Little Animals by Him Observed in Rain-Well-Sea. and Snow Water; as Also in Water Wherein Pepper Had Lain Infused. Philosophical Transactions of the Royal Society of London, 12(133-142), 821831. doi:10.1098/rstl.1677.0003

9. Slots J, MacDonald ES, Nowzari H. (1999). Infectious aspects of periodontal regeneration. Periodontology 2000, 19(1), 164-172.

10. Socransky SS, Haffajee AD, Cugini MA, Smith $\mathrm{C}$, Kent Jr RL. Microbial complexes in subgingival plaque. J Clin Periodontol 1998;25:134e44.

11. Socransky SS, Haffajee AD. Dental biofilms: difficult therapeutic targets. Periodontol 2000 2002;28:12e55.

12. Ö. Yilmaz, "The chronicles of Porphyromonas gingivalise: the microbium, the human oral epithelium and their interplay," Microbiology, 2008 ; 154, (10): 2897-2903.

13. Y.-M. Wu, J. Yan, L.-L. Chen, and Z.-Y. Gu, "Association between infection of different strains of Porphyromonas gingivalis and Actinobacillus actinomycetemcomitans in subgingival plaque and clinical parameters in chronic periodontitis," Journal of Zhejiang University B, 2007; 8, (2): 121-131.

14. X. Lin, J. Wu, and H. Xie, "Porphyromonas gingivalis minor fimbriae are required for cell-cell interactions," Infection and Immunity, 2006; 74, (10): 6011-6015.

15. De Andrade KQ, Almeida-da-Silva C L C, \&Coutinho-SilvaR. Immunological Pathways Triggered by Porphyromonasgingivalis and Fusobacteriumnucleatum: Therapeutic Possibilities? Mediators of Inflammation, 2019, 1-20. doi: $10.1155 / 2019 / 7241312$

16. Rylev, M., \& Kilian, M. (2008). Prevalence and distribution of principal periodontal pathogens worldwide. Journal of Clinical Periodontology, 35, 346-361. doi:10.1111/j.1600-051x.2008.01280.x

17. Li, Y., Guo, H., Wang, X., Lu, Y., Yang, C., \& Yang, P. (2015). Coinfection with Fusobacterium nucleatum can enhance the attachment and invasion of Porphyromonas gingivalis or Aggregatibacter actinomycetemcomitans to human gingival epithelial cells. Archives of Oral Biology, 60(9), 1387-1393. doi:10.1016/j.archoralbio.2015.06.017

18. Wade, W.G. The oral microbiome in health and disease. Pharmacol. Res. 2013; 69: 137-143. [CrossRef]

19. Aas, J.A.; Paster, B.J.; Stokes, L.N.; Olsen, I.; Dewhirst, F.E. Defining the normal bacterial flora of the oral cavity. J. Clin. Microbiol. 2005; 43: 5721-5732. [CrossRef] 
20. Aagaard K, Riehle K, Ma J, Segata N, Mistretta TA, Coarfa C, Raza S, Rosenbaum S, Van den Veyver I, Milosavljevic A et al.: A metagenomic approach to characterization of the vaginal microbiome signature in pregnancy. PLoS ONE 2012, 7:e36466.

21. Segata N, Haake SK, Mannon P, Lemon KP, Waldron L, Gevers D, Huttenhower C, Izard J: Composition of the adult digestive tract bacterial microbiome based on seven mouth surfaces, tonsils, throat and stool samples. Genome Biol 2012; 13: R42.

22. Han YW, Wang X: Mobile microbiome oral bacteria in extra-oral infections and inflammation. J Dent Res 2013.

23. Gharbia SE, Shah HN: Fusobacterium nucleatum subsp. fusiforme subsp. nov. and Fusobacterium nucleatum subsp. animalis subsp. nov. as additional subspecies within Fusobacterium nucleatum. Int J Syst Bacteriol 1992, 42: 296-298.

24. Gharbia SE, Shah HN: Heterogeneity within Fusobacterium nucleatum, proposal of four subspecies. Lett Appl Microbiol 1990; 10: 105-108.

25. Allen-Vercoe E, Strauss J, Chadee K: Fusobacterium nucleatum: an emerging gut pathogen? Gut Microbes 2011; 2: 294-298.

26. Han YW: Fusobacterium nucleatum interaction with host cells. In Oral Microbial Communities: Genomic Inquiry and Interspecies Communication. Edited by Kolenbrander P. ASM Press; 2011.

27. Rickard AH, Gilbert P, High NJ, Kolenbrander PE, Handley PS: Bacterial coaggregation: an integral process in the development of multi-species biofilms. Trends Microbiol 2003; 11: 94-100.

28. Kaplan A, Kaplan CW, He X, McHardy I, Shi W, Lux R: Characterization of aid1, a novel gene involved in Fusobacterium nucleatum interspecies interactions. Microb Ecol 2014; 68: 379-387.

29. Kaplan CW, Lux R, Haake SK, Shi W: The Fusobacterium nucleatum outer membrane protein $\mathrm{RadD}$ is an arginineinhibitable adhesin required for inter-species adherence and the structured architecture of multispecies biofilm. Mol Microbiol 2009;71: 35-47.

30. Kaplan CW, Ma X, Paranjpe A, Jewett A, Lux R, Kinder-Haake S, Shi W: Fusobacterium nucleatum outer membrane proteins Fap2 and RadD induce cell death in human lymphocytes. Infect Immun 2010; 78: 4773-4778.

31. Bachrach G, Ianculovici C, Naor R, Weiss EI: Fluorescence based measurements of Fusobacterium nucleatum coaggregation and of fusobacterial attachment to mammalian cells. FEMS Microbiol Lett 2005; 248: 235-240.

32. Xu M, Yamada M, Li M, Liu H, Chen SG, Han YW: FadA from Fusobacterium nucleatum utilizes both secreted and nonsecreted forms for function- al oligomerization for attachment and invasion of host cells. J Biol Chem 2007; 282: 25000-25009.

33. Gupta S, Ghosh SK, Scott ME, Bainbridge B, Jiang B, Lamont RJ, McCormick TS, Weinberg A: Fusobacterium nucleatumassociated beta-defensin inducer (FAD-I): identification, isolation, and functional evaluation. J Biol Chem 2010; 285: 36523-36531.

34. Kostic AD, Gevers D, Pedamallu CS, Michaud M, Duke F, Earl AM, Ojesina AI, Jung J, Bass AJ, Tabernero J et al.: Genomic analysis identifies association of Fusobacterium with colorectal carcinoma. Genome Res 2012; 22: 292-298.

35. Han YW, Shi W, Huang GT, Kinder Haake S, Park NH, Kuramitsu H, Genco RJ: Interactions between periodontal bacteria and human oral epithelial cells: Fusobacterium nucleatum adheres to and invades epithelial cells. Infect Immun 2000; 68: 3140-3146.

36. Park SR, Kim DJ, Han SH, Kang MJ, Lee JY, Jeong YJ, Lee SJ, Kim TH, Ahn SG, Yoon JH et al.: Diverse Toll-like receptors mediate cytokine production by Fusobacterium nucleatum and Aggregatibacter actinomycetemcomitans in macrophages. Infect Immun 2014; 82: 1914-1920.

37. Chaushu S, Wilensky A, Gur C, Shapira L, Elboim M, Halftek G, Polak D, Achdout H, Bachrach G, Mandelboim O: Direct recognition of Fusobacterium nucleatum by the NK cell natural cytotoxicity receptor NKp46 aggravates periodontal disease. PLoS Pathog 2012, 8:e1002601.

38. Rubinstein MR, Wang X, Liu W, Hao Y, Cai G, Han YW: Fusobacterium nucleatum promotes colorectal carcinogenesis by modulating E-cadherin/b-catenin signaling via its FadA adhesin. Cell Host Microbe 2013; 14: 195-206.

39. Kolenbrander PE, Andersen RN, Moore LV. Coaggregation of Fusobacterium nucleatum, Selenomonas flueggei, Selenomonas infelix, Selenomonas noxia, and Selenomonas sputigena with strains from 11 genera of oral bacteria. Infect Immun 1989; 57(10): 3194-3203.

40. Bradshaw DJ, Marsh PD, Watson GK et al. Role of Fusobacterium nucleatum and coaggregation in anaerobe survival in planktonic and biofilm oral microbial communities during aeration. Infect Immun 1998; 66(10): 4729-4732.

41. Coppenhagen-Glazer S, Sol A, Abed J et al. Fap2 of Fusobacterium nucleatum is a galactose-inhibitable adhesin involved in coaggregation, cell adhesion, and preterm birth. Infect Immun 2015; 83(3): 1104-1113.

42. Henderson IR, Navarro-Garcia F, Desvaux M et al. Type $\mathrm{V}$ protein secretion pathway: the autotransporter story. Microbiol Mol Biol Rev 2004; 68(4): 692-744. 
43. Bullard B, Lipski S, Lafontaine ER. Regions important for the adhesin activity of Moraxella catarrhalis Hag. BMC Microbiol 2007; 7: 65.

44. Lipski SL, Akimana C, Timpe JM et al. The Moraxella catarrhalis autotransporter $\mathrm{McaP}$ is a conserved surface protein that mediates adherence to human epithelial cells through its N-terminal passenger domain. Infect Immun 2007; 75(1): 314 324.

45. Heras B, Totsika M, Peters KM et al. The antigen 43 structure reveals a molecular Velcro-like mechanism of autotransporter-mediated bacterial clumping. Proc Natl Acad Sci USA 2014; 111(1): 457-462.

46. Klemm P, Hjerrild L, Gjermansen $M$ et al. Structure-function analysis of the selfrecognizing antigen 43 autotransporter protein from Escherichia coli. Mol Microbiol 2004; 51(1): 283-296.

47. Sherlock O, Schembri MA, Reisner A et al. Novel roles for the AIDA adhesin from diarrheagenic Escherichia coli: cell aggregation and biofilm formation. J Bacteriol 2004; 186(23): 8058-8065.

48. Valle J, Mabbett AN, Ulett GC et al. UpaG, a new member of the trimeric autotransporter family of adhesins in uropathogenic Escherichia coli. J Bacteriol 2008; 190 (12): 4147-4161.

49. Capecchi B, Adu-Bobie J, Di Marcello F et al. Neisseria meningitidis NadA is a new invasin which promotes bacterial adhesion to and penetration into human epithelial cells. Mol Microbiol 2005; 55(3): 687-698.

50. Moore WE, Moore LV: The bacteria of periodontal diseases. Periodontology 2000 1994; 5: 66-77.

51. Yang NY, Zhang Q, Li JL, Yang SH, Shi Q: Progression of periodontal inflammation in adolescents is associated with increased number of Porphyromonas gingivalis, Prevotella intermedia, Tannerella forsythensis, and Fusobacterium nucleatum. Int J Paediatr Dent 2014; 24: 226-233.

52. Riep B, Edesi-Neuss L, Claessen F, Skarabis H, Ehmke B, Flemmig TF, Bernimoulin JP, Gobel UB, Moter A: Are putative periodontal pathogens reliable diagnostic markers? J Clin Microbiol 2009, 47: 1705-1711.

53. Lourenco TG, Heller D, Silva-Boghossian CM, Cotton SL, Paster BJ, Colombo AP: Microbial signature profiles of periodontally healthy and diseased patients. J Clin Periodontol 2014, 41: 1027-1036.

54. Moon JH, Lee JH, Lee JY: Subgingival microbiome in smokers and non-smokers in Korean chronic periodontitis patients. Mol Oral Microbiol 2014. [Epub ahead of print].

55. Mason MR, Preshaw PM, Nagaraja HN, Dabdoub SM, Rahman A, Kumar PS: The subgingival microbiome of clinically healthy current and never smokers. ISME J 2014. [Epub ahead of print].
56. Casarin RC, Barbagallo A, Meulman T, Santos VR, Sallum EA, Nociti FH, Duarte PM, Casati MZ, Goncalves RB: Subgingival biodiversity in subjects with uncontrolled type-2 diabetes and chronic periodontitis. J Periodontal Res 2013; 48: 30-36.

57. Kuriyama T, Nakagawa K, Kawashiri S, Yamamoto E, Nakamura S, Karasawa T: The virulence of mixed infection with Streptococcus constellatus and Fusobacterium nucleatum in a murine orofacial infection model. Microbes Infect 2000; 2: $1425-1430$.

58. Nagashima H, Takao A, Maeda N: Abscess forming ability of streptococcus milleri group: synergistic effect with Fusobacterium nucleatum. Microbiol Immunol 1999; 43: 207-216.

59. Settem RP, El-Hassan AT, Honma K, Stafford GP, Sharma A: Fusobacterium nucleatum and Tannerella forsythia induce synergistic alveolar bone loss in a mouse periodontitis model. Infect Immun 2012; 80: 2436-2443.

60. Polak D, Wilensky A, Shapira L, Halabi A, Goldstein D, Weiss EI, Houri-Haddad Y: Mouse model of experimental periodontitis induced by Porphyromonas gingivalis/Fusobacterium nucleatum infection: bone loss and host response. J Clin Periodontol 2009; 36: 406-410.

61. Kesavalu L, Sathishkumar S, Bakthavatchalu V, Matthews C, Dawson D, Steffen M, Ebersole JL: Rat model of polymicrobial infection, immunity, and alveolar bone resorption in periodontal disease. Infect Immun 2007; 75: 1704-1712.

62. Rogers, A. H. (1998). Studies on fusobacteria associated with periodontal diseases. Australian Dental Journal, 43(2): 105-109.

63. Arenas Rodrigues VA, de Avila ED, Nakano V, Avila-Campos MJ. Qualitative, quantitative and genotypic evaluation of Aggregatibacter actinomycetemcomitans and Fusobacterium nucleatum isolated from individuals with different periodontal clinical conditions. Anaerobe. 2018 Aug;52:5058. doi: 10.1016/j.anaerobe.2018.05.015. Epub 2018 May 29.

64. Feng X, Zhang L, Xu L, Meng H, Lu R, Chen Z, Shi D, Wang X. Detection of eight periodontal microorganisms and distribution of Porphyromonas gingivalis fimA genotypes in chinese patients with aggressive periodontitis. J Periodontol. 2014; 85: 150-159.

65. Hartenbach FARR, Silva-Boghossian CM, Colombo APV.The effect of supragingival biofilm re-development on the subgingival microbiota in chronic periodontitis. Arch Oral Biol. 2018 Jan; 85: 51-57. doi: 10.1016/j.archoralbio.2017.10.007. Epub 2017 Oct 10.

66. Didilescu AC, Rusu D, Anghel A, Nica L, Iliescu A, Greabu M, Bancescu G, Stratul SI. Investigation of six selected bacterial species in endo-peri- 
odontal lesions. Int Endod J. 2012; 45: 282-293. [PubMed] [Google Scholar]

67. Saygun I, Nizam N, Keskiner I, Bal V, Kubar A, Açıkel C, Serdar M, Slots J.Salivary infectious agents and periodontal disease status. J Periodontal Res. 2011 Apr; 46(2): 235-9. doi: 10.1111/j.16000765.2010.01335.x. Epub 2011 Jan 25.PMID: 21261620

68. Fujii R, Saito Y, Tokura Y, Nakagawa KI, Okuda $\mathrm{K}$, Ishihara K. Characterization of bacterial flora in persistent apical periodontitis lesions. Oral Microbiol Immunol. 2009; 24: 502-505. [PubMed] [Google Scholar

69. Siqueira JF, Jr, Rocas IN, Paiva SS, Magalhaes KM, Guimaraes-Pinto T. Cultivable bacteria in infected root canals as identified by $16 \mathrm{~S}$ rRNA gene sequencing. Oral Microbiol Immunol. 2007; 22: 266-271. [PubMed] [Google Scholar]

70. Triches TC, de Figueiredo LC, Feres M, de Freitas SF, Zimmermann GS, Cordeiro MM. Microbial profile of root canals of primary teeth with pulp necrosis and periradicular lesion. J Dent Child (Chic) 2014;81:14-19. [Abstract] [Google Scholar]

71. Liu P, Liu Y, Wang J, Guo Y, Zhang Y, Xiao S. Detection of fusobacterium nucleatum and fadA adhesin gene in patients with orthodontic gingivitis and non-orthodontic periodontal inflammation. PLoS One. 2014; 9: e85280

72. Binder Gallimidi A, Fischman S, Revach B, Bulvik R, Maliutina A, Rubinstein AM, Nussbaum G, Elkin M. 2015. Periodontal pathogens Porphyromonas gingivalis and Fusobacterium nucleatum promote tumor progression in an oral-specific chemical carcinogenesis model. Oncotar-get 6: 22613-22623. http://dx.doi.org/10.18632/oncotarget. 4209 .

73. Whitmore SE, Lamont RJ. 2014. Oral bacteria and cancer. PLoS Pathog

74. Sears CL, Garrett WS. 2014. Microbes, microbiota, and colon cancer. Cell Host Microbe 15: 317-328. http://dx.doi.org/10.1016/ j.chom.2014.02.007. 10: e1003933. http://dx.doi.org/10.1371/journal. ppat. 1003933.

75. Chen W, Liu F, Ling Z, Tong X, Xiang C. 2012. Human intestinal lumen and mucosa-associated microbiota in patients with colorectal cancer. PloS One 7:e39743.http://dx.doi.org/10.1371/journal. pone.0039743.

76. Marchesi JR, Dutilh BE, Hall N, Peters WH, Roelofs R, Boleij A, Tjalsma H: Towards the human colorectal cancer microbiome. PLoS ONE 2011, 6:e20447.

77. Castellarin M, Warren RL, Freeman JD, Dreolini L, Krzywinski M, Strauss J, Barnes R, Watson P, Allen-Vercoe E, Moore RA et al.: Fusobacterium nucleatum infection is prevalent in human colorectal carcinoma. Genome Res 2012; 22: 299-306.
78. Swidsinski A, Dorffel Y, Loening-Baucke V, Theissig F, Ruckert JC, Ismail M, Rau WA, Gaschler D, Weizenegger M, Kuhn S et al.: Acute appendicitis is characterised by local invasion with Fusobacterium nucleatum/necrophorum. Gut 2011; 60: 34-40.

79. Swidsinski A, Dorffel Y, Loening-Baucke V, Tertychnyy A, Biche- Ool S, Stonogin S, Guo Y, Sun ND: Mucosal invasion by fusobacteria is a common feature of acute appendicitis in Germany, Russia, and China. Saudi J Gastroenterol 2012; 18: 55-58.

80. Zhong D, Brower-Sinning R, Firek B, Morowitz MJ: Acute appendicitis in children is associated with an abundance of bacteria from the phylum Fusobacteria. J Pediatr Surg 2014; 49: 441-446.

81. Han YW: Oral health and adverse pregnancy outcomes - what's next? J Dent Res 2011; 90: 289-293.

82. Han YW: Can oral bacteria cause pregnancy complications? Womens Health (Lond Engl) 2011; 7: 401-404.

83. Hill GB: Investigating the source of amniotic fluid isolates of fusobacteria. Clin Infect Dis 1993, 16(Suppl. 4): S423-S424.

84. Stergiopoulou T, Walsh TJ. Fusobacterium necrophorum otitis and mastoiditis in infants and young toddlers. Eur J Clin Microbiol Infect Dis. 2016 May; 35(5): 735-40. doi: 10.1007/s10096016-2612-1. Epub 2016 Mar 7. Review.PMID: 26951264

85. Fischer JB, Prout A, Blackwood RA, Warrier K. Lemierre Syndrome Presenting as Acute Mastoiditis in a 2-Year-Old Girl with Congenital Dwarfism. Infect Dis Rep. 2015 Jun 8; 7(2): 5922. doi: 10.4081/idr.2015.5922. eCollection 2015 Apr 15. PMID:26294952

86. Brook I: Fusobacterial infections in children. Curr Infect Dis Rep 2013; 15: 288-294.

87. Elkaim R, Dahan M, Kocgozlu L, Werner S, Kanter D, Kretz JG, Tenenbaum H: Prevalence of periodontal pathogens in subgingival lesions, atherosclerotic plaques and healthy blood vessels: a preliminary study. J Periodontal Res 2008; 43: 224-231.

88. Sparks Stein P, Steffen MJ, Smith C, Jicha G, Ebersole JL, Abner E, Dawson D 3rd: Serum antibodies to periodontal pathogens are a risk factor for Alzheimer's disease. Alzheimers Dement 2012; 8: 196-203.

89. Ortiz P, Bissada NF, Palomo L, Han YW, Al-Zahrani MS, Panneerselvam A, Askari A: Periodontal therapy reduces the severity of active rheumatoid arthritis in patients treated with or without tumor necrosis factor inhibitors. J Periodontol 2009; 80: 535-540.

90. Gaetti-Jardim E Jr, Marcelino SL, Feitosa AC, Romito GA, Avila-Campos MJ.Quantitative de- 
tection of periodontopathic bacteria in atherosclerotic plaques from coronary arteries. J Med Microbiol. 2009 Dec; 58 (Pt 12): 1568-75. doi: 10.1099/jmm.0.013383-0. Epub 2009 Aug 13. PMID: 19679682

91. Borgo PV, Rodrigues VA, Feitosa AC, Xavier KC, Avila-Campos MJ , Association between periodontal condition and subgingival microbiota in women during pregnancy: a longitudinal study. J Appl Oral Sci. 2014 Nov-Dec; 22(6): 528-33. doi: 10.1590/1678-775720140164.

92. Akcalı A, Bostanci N, Özçaka Ö, Öztürk-Ceyhan B, Gümüş P, Buduneli N, Belibasakis GN.. Association between polycystic ovary syndrome, oral microbiota and systemic antibody responses. PLoS One. 2014 Sep 18; 9(9): e108074. doi: 10.1371/journal.pone.0108074. eCollection 2014.

93. Han YW, Shen T, Chung P, Buhimschi IA, Buhimschi CS. Uncultivated bacteria as etiologic agents of intra-amniotic inflammation leading to preterm birth. J Clin Microbiol. 2009; 47: 38-47. [PMC free article] [PubMed] [Google Scholar]

94. Tateishi F, Hasegawa-Nakamura K, Nakamura T, Oogai Y, Komatsuzawa H, Kawamata K, Douchi T, Hatae M, Noguchi K. Detection of Fusobacterium nucleatum in chorionic tissues of high-risk pregnant women.J Clin Periodontol. 2012 May; 39(5): 417-24. doi: 10.1111/j.1600-051X.2012.01855.x. Epub 2012 Feb 6.
95. Warren RL, Freeman DJ, Pleasance S, Watson P, Moore RM, Cochrane K, Allen-Vercoe E, Robert A Holt RA. Co-occurrence of anaerobic bacteria in colorectal carcinomas. Microbiome. 2013; $1: 16$.

96. Zhang Y, Suehiro Y, Shindo Y, Sakai K, Hazama S, Higaki S, Sakaida I, Oka M, Yamasaki T. Long-fragment DNA as a potential marker for stool-based detection of colorectal cancer. Oncol Lett. 2015 Jan; 9(1): 454-458. Epub 2014 Oct 24.

97. Barak S, Oettinger-Barak O, Machtei EE, Sprecher H, Ohel G.Evidence of periopathogenic microorganisms in placentas of women with preeclampsia. J Periodontol. 2007 Apr; 78(4): 670-6.

98. Cahill RJ, Tan S, Dougan G, O'Gaora P, Pickard D, Kennea N, Sullivan MH, Feldman RG, Edwards AD.Universal DNA primers amplify bacterial DNA from human fetal membranes and link Fusobacterium nucleatum with prolonged preterm membrane rupture. Mol Hum Reprod. 2005 Oct; 11(10): 761-6. Epub 2005 Oct 27

99. Brook I. Fusobacterial infections in children. J Infect. 1994 Mar; 28(2): 155-65.

100. Témoin S, Chakaki A, Askari A, El-Halaby A, Fitzgerald S, Marcus RA, Han YW, Bissada NF.Identification of oral bacterial DNA in synovial fluid of arthritis patients with native and failed prosthetic joints.J Clin Rheumatol. 2012 Apr; 18(3): 117-121. doi: 10.1097/RHU. 0b013e3182500c95 


\title{
Резиме
}

\section{ПРИСУСТВО И УЛОГА НА FUSOВАСТЕRIUМ NUCLEATUМ ВО УСТАТА И НАДВОР ОД НЕА}

\author{
Урим Тефику ${ }^{1}$, Мирјана Поповска², Амела Цана ${ }^{3}$, Линдита Зендели-Бешети ${ }^{3}$, \\ Биљбиљ Речица ${ }^{4}$, Ана Спасовска-Ѓорговска ${ }^{5}$, Спиро Спасовски ${ }^{6}$ \\ ${ }^{1}$ „Дента мед“, Приштина, Република Косово \\ ${ }^{2}$ Универзитетски стоматолошки клинички центар, Оддел за пародонтологија и орална патологија, \\ Стоматолошки факултет, Универзитет „Св. Кирил и Методиј“, Скопје, РС Македонија \\ ${ }^{3}$ Универзитетски стоматолошки клинички центар, Оддел за пародонтологија и орална патологија, \\ Скопје, РС Македонија \\ ${ }^{4}$ Универзитетски стоматолошки клинички центар, Оддел за стоматолошки итни случаи, Приштина, \\ Република Косово, \\ ${ }^{5}$ ПЗУ „Илинден 96“, Скопје, РС Македонија \\ ${ }^{6}$ „Др. Спасовски“, Скопје, РС Македонија
}

Вовед: Еден од најважните видови микроорганизми во усната празнина и кај здрави и кај болни индивидуи е Fusobacterium nucleatum. Иако е присутен како нормален жител, овој грам-негативен патоген е доминантен во пародонталната болест и е вклучен во многу инвазивни инфекции кај популацијата, акутни и хронични воспалителни состојби, како и многу несакани дејства со фатален завршеток.

Цел: Да се утврди улогата на F. nucleatum во развојот на полимикробни биофилм во оралниот медиум преку следење на литературата и надвор од неа.

Материјал и метод: Систематски преглед на литературата во врска со застапеноста и улогата на F. nucleatum преку достапните клинички испитувања, прегледи на литература, оригинални истражувања и статии објавени по електронски пат во Pub Med и Google Scholar.

Заклучок: Присуството на Fusobacterium nucleatum е најчесто поврзано со здравствената состојба на поединците. Овие анаеробни бактерии играат клучна улога во оралните патолошки состојби и се откриени кај многу системски нарушувања, предизвикувајќ комплексни патогенетски промени веројатно поради случувањата во различни клетки и преку различни механизми за вирулентност. Најчести заболувања и состојби во усната празнина поврзани со F.nucleatum ce гингивитис $(\mathrm{G})$, хронична пародонтопатија $(\mathrm{CH})$, агресивна пародонтоптија $(\mathrm{AgP})$, ендо-перио инфекции (Е-P), хроничен апикален периодонтитис (РСНА). Исто така, бактеријата е идентификувана и откриена кај многу системски нарушувања, како што се коронарната срцева болест (CVD), патолошката бременост (P); синдромот на полицистични јајници (PCOS), високоризичната бременост (HRP), колоректалниот карцином (CRC); прееклампсијата (PE); ревматоидниот артритис (RA); и остеоартритисот (OA).

Клучни зборови: пародонтопатија, Fusobacterium nucleatum, патогенеза 